\title{
Erratum to: A Fixed-Precision Sequential Sampling Plan for the Potato Tuberworm Moth, Phthorimaea operculella Zeller (Lepidoptera: Gelechidae), on Potato Cultivars
}

\author{
M Shahabi, A Rajabpour \\ Dept of Plant Protection, Faculty of Agriculture, Ramin Agriculture and Natural Resources Univ of Khuzestan, Ahwaz, Khuzestan Province, Iran
}

\section{Erratum to: Neotrop Entomol}

DOI 10.1007/s13744-017-0487-1

Due to an unfortunate turn of events, the surname of the first author appeared incorrectly in the original publication and should have read Shahabi.

The correct representation of the authors' names and their affiliation is listed here and should be treated as definitive. We apologize to authors and readers for the inconvenience. 